\title{
Reliability Based Analysis of a Pin Connected Truss using Random Field Finite Element Method (RFEM)
}

\author{
Gökhan Yazıcı ${ }^{1}$, Ahmet Can Mert ${ }^{2 *}$ \\ 1 İstanbul Kültür University, Faculty of Engineering, Departmant of Civil Engineering, İstanbul, Turkey, (ORCID: 0000-0002-6719-9152), gokhanyazici@iku.edu.tr \\ 2* İstanbul Kültür University, Faculty of Engineering, Departmant of Civil Engineering, İstanbul, Turkey, (ORCID: 0000-0002-2483-1330), a.mert@iku.edu.tr
}

(First received 30 April 2021 and in final form 21 November 2021)

(DOI: 10.31590 /ejosat.)

ATIF/REFERENCE: Yazıc1, G., Mert, A.C. (2021). Reliability Based Analysis of a Pin Connected Truss using Random Field Finite Element Method. European Journal of Science and Technology, (27), 898-901.

\begin{abstract}
Wood is an anisotropic structural material with highly variable mechanical properties. The mechanical properties of wood used in timber structures depend on several factors including biological origins, environmental conditions and manufacturing processes. Even the timber members from the same tree are prone to variations in their mechanical properties due to the presence of local defects such as knots and resin pockets. Therefore, the reliability assessment of timber structures needs to take into account the variability of the mechanical properties of timber members. In this study, Random Field Element Method (RFEM) was used to carry out the reliability assessment of a pin connected timber roof truss. The modulus of elasticity were selected as the random field variables for the timber members. Modelling and analysis of the timber truss was conducted using the ANSYS finite element analysis software. The impact of the variation of the mechanical properties of the timber members on the deflections of the truss system used in this study are presented in the conclusions.
\end{abstract}

Keywords: Random Field Finite Element Method (RFEM), Timber Structures, Reliability Assessment.

\section{Rastgele Alanlı Sonlu Elemanlar Analizi (RFEM) Kullanılarak Mafsallı Birleşimli Bir Ahşap Kafesin Güvenirliğe Dayalı Analizi}

$\ddot{O} \mathbf{z}$

Ahşap, mekanik özellikleri yüksek değişkenlik gösteren anizotrop bir yapısal malzemedir. Yapılarda kullanılan ahşap elemanlarda mekanik özellikler biyolojik köken, çevresel koşullar ve üretim sürecini içeren birçok etkene bağlıdır. Aynı ağaçtan elde edilen ahşap elemanlar dahi, boğumlar ve reçine kovukları gibi yerel kusurlardan ötürü mekanik özelliklerde değişkenlik eğilimindedir. Bu nedenle ahşap yapıların güvenirlik değerlendirmelerinde, ahşap elemanlardaki mekanik özellik değişkenliğinin göz önüne alınması gerekmektedir. Çalışmada, rastgele alanlı sonlu elemanlar yöntemi (RFEM) kullanılarak mafsallı birleşimli bir ahşap kafesin güvenirlik analizi yapılmıştır. Ahşap elemanların elastisite modulü rastgele alan olarak tanımlanmıştır. Kafes modeli ve analizler ANSYS sonlu elemanlar yazılımı ile gerçekleştirilmiştir. Ahşap elemanların mekanik özelliklerindeki değişimin kafes sistemindeki çökmelere etkisi kullanılarak sonuçlar sunulmuştur.

Anahtar Kelimeler: Rastgele Alanlı Sonlu Elemanlar Yöntemi (RFEM), Ahşap Yapılar, Güvenirlik Değerlendirmesi.

\footnotetext{
* Corresponding Author: a.mert@iku.edu.tr
} 


\section{Introduction}

Wood is a widely used structural material with significantly variable mechanical properties. Since wood is orthotropic, the mechanical properties of wood are different in the longitudinal, transverse and radial directions (Larsen, 2001). The mechanical properties of wood used in timber structures depend on several factors including biological origins, environmental conditions, manufacturing processes and loading history. Experimental investigation of the mechanical properties for various species of solid raw and engineered wood members have been vigorously investigated and are widely available in the literature (Asdrubali et al., 2017; Sun et al., 2020).

By its nature, there are randomly distributed weak spots in wood members such as knots, grain deviations, compression wood, decay, bark and resin pockets. The segments of wood between these local defects are referred to as clear wood. Experimental studies for determining the mechanical properties are generally conducted on clear wood samples and the mechanical properties vary significantly between and within timber members due to the presence and distribution of weak zones through their length (Larsen, 2001). According to Wood Handbook (Forest Products Laboratory, 1999), the coefficients of variation $(\mathrm{COV})$ for strength and modulus of Elasticity is approximately $20 \%$ for solid timber members. (Arwade et al., 2010).

\section{Material Properties and Modelling}

\subsection{Mechanical Properties of Wood}

Mechanical properties which are employed for truss model are presented in this section. All the properties except modulus of elasticity of wood (E) was taken as constants. E of wood was defined as spatially varying parameter by truss member. This variation was modelled by using random field theory having a correlation length equals to the truss member dimensions.

Poisson's ratio $(v)$ of wood was taken as 0.3 and the behaviour was assumed isotropic. Natural orthotropic behaviour of wood was not considered in the study since 2D truss deflections in plain-strain condition was not affected by the variation of orthotropic $v$. Young's Modulus of wood was assigned as spatially varying parameter with $13 \mathrm{GPa}$ mean and COV of $20 \%$. Spatial distribution of $\mathrm{E}$ was modelled as Gaussian random field, and the parameter generation details were given in the following section.

\subsection{Model Information}

The model used in the analysis is a timber truss described by Blass et al. (1995). Span length is $22.5 \mathrm{~m}$, and maximum heigth at mid-point is $3 \mathrm{~m}$. Top chord has $10^{\circ}$ slope, and there are seven vertical and ten diagonal members. The cross-section of upper, bottom chords, and intermediate members are $200 \times 200,200 \times$ 160 and $160 \times 160 \mathrm{~mm}^{2}$, respectively (Villar et al., 2016). The full geometry of the employed model is given in Figure 1.

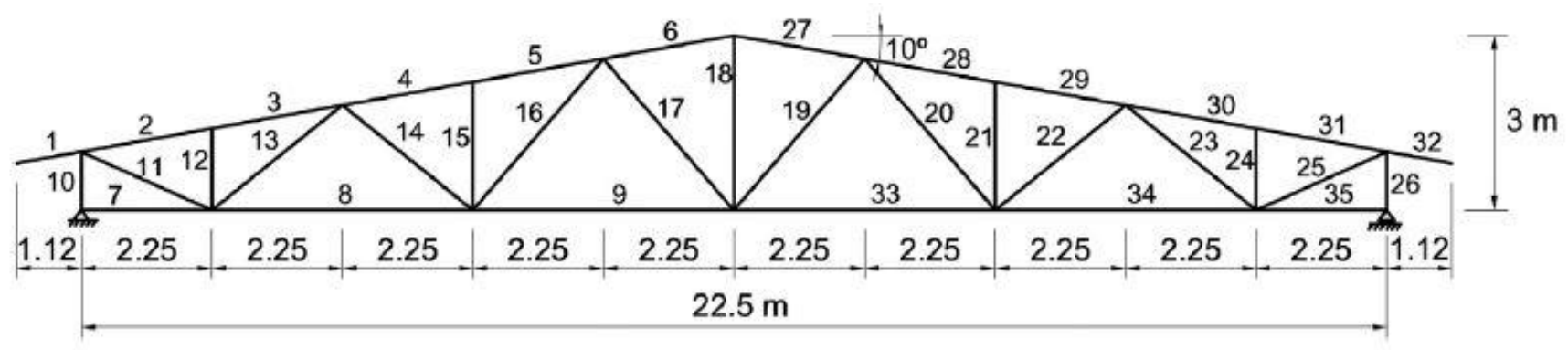

Figure 1. Timber truss model

Variation of the mechanical properties of wood within the members significantly complicates the assessment of the reliability of timber structures. In this study, Random Field Element Method (RFEM) was used to carry out the reliability assessment of a pin connected timber roof truss by considering the variation of mechanical properties within the members. The method is based on random field theory, which accounts for the variation of any random variable in space, is an efficient for uncertainty in one, two or three-dimensional spatial variation of material properties (Vanmarcke, 2010). RFEM requires definition of random field for the spatially varying parameter by correlation function $\rho(\tau)$. The parameter $\tau$ represents the distance between random variables in the field. The correlation function also contains the main parameter for random field which is called scale of fluctuation or correlation length $(\theta)$, and is given for an exponential Markovian type as Equation 1:

$$
\rho(\tau)=\exp \left(-\frac{2|\tau|}{\theta}\right)
$$

In the present study, modulus of elasticity for wood was modelled as Gaussian random field with exponential correlation function as Equation 1.
Modelling was conducted in finite element software ANSYS. Loads were assigned both top and bottom chord joints. Each joint on the top chord was subjected to $25 \mathrm{kN}$ vertical load, and bottom chord joints were loaded with $5 \mathrm{kN}$ vertical force. The loading condition was selected provided that the deflection does not exceed $1 / 300$ of the span.

\subsection{Random Field Generation}

Random field of E was generated by using MATLAB code with given mean and COV values. Random parameter was assumed as normally distributed. Correlation length of the field is selected so that the value equals to the member length. Thus, each member in the truss system has their own random E parameter. 1000 realizations were performed for the generated random field which means each member takes a thousand different $\mathrm{E}$ values having $13 \mathrm{GPa}$ mean and $20 \% \mathrm{COV}$. By this method, the variation of rigidity due to any defects in the wood was taken into consideration. Figure 2 depicts a representative iteration with an arbitrary realization of $\mathrm{E}$ field assigned. The representation model 


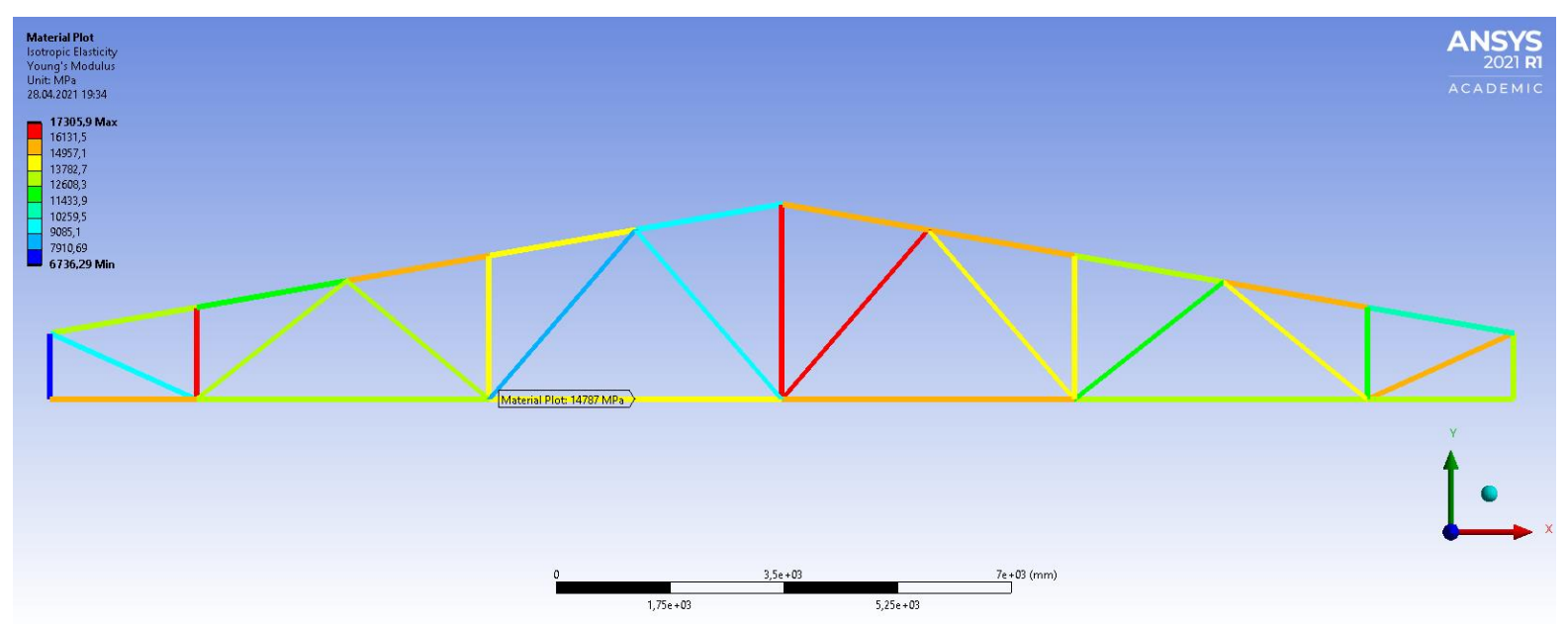

Figure 2. Representative E field assigned to the truss system

shows the case of truss system construction with the same wood material but having uncertain rigidity. E values vary between 6$17 \mathrm{GPa}$ even the mean value is $13 \mathrm{GPa}$. Each realization contains the similar variation in rigidity which constructs output probability distribution of deflections.

\section{Methodology}

The study aims to present the effect of rigidity variation in timber trusses. Initially, the deterministic output of deflection was obtained with constant E values as the mean $13 \mathrm{GPa}$. Spatial variation of $\mathrm{E}$ was then defined as random field by MATLAB code. Realizations of the field were consequently assigned into each member of the truss system in ANSYS. Finite element analyses were performed for each realization, and deflection output for each analysis iteration was recorded. 1000 realizations formed the output distribution of deflections, and a probability density function (PDF) with proper distribution was fitted to the histogram of the outputs. PDF of deflection was subsequently employed to compare the mean deflection with the deterministic result. Finally, statistical information of the output PDF was presented, and the effect of rigidity variation was investigated. Figure 3 presents the main framework of the method explained.

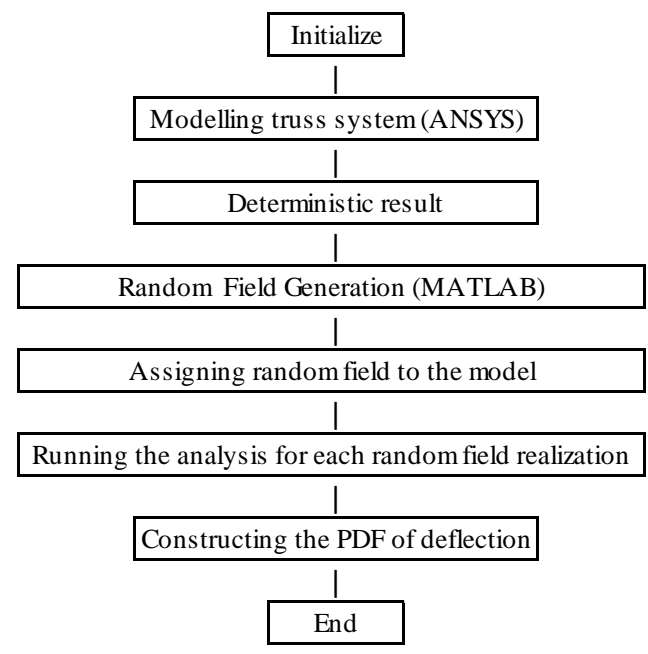

Figure 3. Flowchart of the method

\section{Analysis Results}

The first step was to perform deterministic analysis with the sprecified mean value of E (13GPa). All the parameters were constant, and the deflection of the mid-span was recorded. Maximum deflection for deterministic analysis was $38.04 \mathrm{~mm}$, which was below $1 / 300$ of the span length of $22.50 \mathrm{~m}(75.00 \mathrm{~mm})$ Subsequently, RFEM model was analysed for each E field realizations in ANSYS. Output distribution of mid-span deflection was obtained, and the result fitted lognormal distribution. Mean of the distribution was $39.95 \mathrm{~mm}$ which differs from the deterministic result. However, range of the deflection values were within $33.68 \mathrm{~mm}$ and $55.81 \mathrm{~mm}$, and the maximum values was approaching the deflection limit of $75 \mathrm{~mm}$ conforming that the variability of rigidity should be taken into consideration. Fitted PDF of the deflection limit is given in Figure 4 with mean value of the distribution and deterministic result to show the deviation.

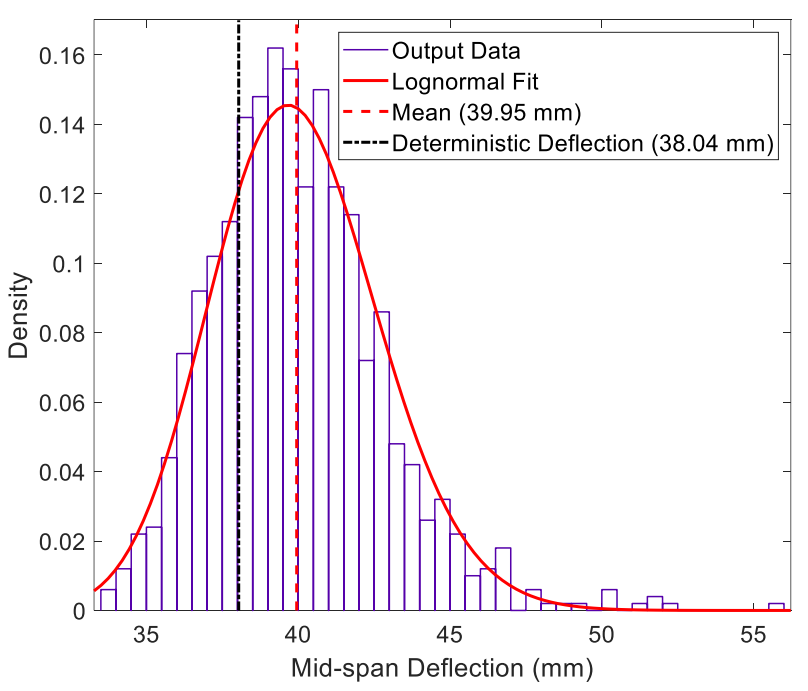

Figure 4. Output PDF of mid-span deflection on the truss

The response PDF depicts that the deterministic result may underestimate the deflection and it may cause misevaluation of the outputs. PDF can also be employed for probabilistic evaluation from which can be estimated probability of failure for a specified deflection limit. Proposed framework allows engineer 
to judge the spatial variation of rigidity parameter and perform reliability assessment.

\section{Conclusions and Recommendations}

The results of the study revealed the necessity of spatial variability of wood rigidity in reliability assessment of pinconnected timber truss. Rigidity changes of the members from the same wood material due to any defects can be modelled by RFEM framework proposed in the present work. The coefficient of variation of the output probability distribution of mid-span deflection on the truss was found $7 \%$ which conforms that the value range may reach up to $56 \mathrm{~mm}$ which approaches the deflection limit $(75 \mathrm{~mm})$ for the given truss geometry. The mean value of the PDF validates that the deterministic analysis with constant $\mathrm{E}$ may underestimate the deflection. Therefore, the use of spatial variability of rigidity is recommended for reliability assessment of pin-connected timber trusses.

\section{References}

Arwade, S. R., Winans, R., Clouston, P. L. (2010). Variability of Compressive Strength of Parallel Strand Lumber. Journal of Engineering Mechanics, 136(4), 405-412.

Asdrubali, F., Ferracuti, B., Lombardi, L., Guattari, C., Evangelisti, L., Grazieschi, G. (2017). A review of structural, thermo-physical, acoustical, and environmental properties of wooden materials for building applications. Building and Environment, 14, 307-332.

Blass, H. J., Aune, P., Choo, B. S., Gorlacher, R., Griffiths, D. R., Hilson, B. O., Racher, P., Steck, G. (1995). Timber engineering STEP2. Design-Details and structural systems. Almere, The Netherlands: The Centrum Hout.

Forest Products Laboratory. (1999). Wood Handbook: Wood as an Engineering Material. USDA, Madison, Wisconsin.

Larsen, H. J. \& BYG (2001). Properties affecting reliability design of timber structures. COSTE24 Seminar on Reliability of timber structures, Coimbra, Portugal, May 4-5, 2001.

Sun, X., He, M., Li, Z. (2020). Novel engineered wood and bamboo composites for structural applications: State-of-art of manufacturing technology and mechanical performance evaluation. Construction and Building Materials, 249, 1-23.

Vanmarcke, E. (2010). Random fields: Analysis and synthesis. New Jersey, USA: World Scientific.

Villar, J. R., Vidal, P., Fernandez, M S., Guaita, M. (2016). Genetic algorithm optimisation of heavy timber trusses with dowel joints according to Eurocode 5. Biosystems Engieering, 144, 115-132. 